\title{
A LUA E O OUTRO LADO DA TERRA: MENSTRUAÇÃO, CONCEPÇÃO E GESTAÇÃO ENTRE AS ARAWETÉ
}

Camila Caux ${ }^{1}$

${ }^{1}$ Universidade Federal do Rio de Janeiro, Museu Nacional, Programa de Pósgraduação em Antropologia Social, Rio de Janeiro/RJ, Brasil

Esta foi a explicação que mais de uma vez ouvi sobre a fisiologia da menstruação: a mulher tem relações sexuais durante todo o mês, até que Jahi, o Lua, aparece "na lua certinha" da mulher, sempre no mesmo período lunar, e "faz descer" matéria acumulada em seu ventre. Com o presente artigo, ${ }^{1}$ pretendo partir desta afirmação para refletir sobre o que aprendi sobre a formação do sangue menstrual, a fecundação e a gestação junto aos Araweté, um povo indígena falante de um idioma da família tupi-guarani e habitante da Terra Indígena Araweté/Ipixuna, no médio curso do rio Xingu (PA), com os quais convivo desde 2010.

O objetivo deste texto é descrever alguns aspectos da fisiologia feminina araweté. Falarei da relação entre menstruação e concepção, da diferença entre matéria menstrual e gestacional, do caráter fecundador do sêmen e sua propriedade autofabricadora, da capacidade "contenedora" do hiro feminino, além do conjunto de restrições parentais durante a gravidez. Darei ênfase também às figuras de Jahi (Lua) e Iwikatin-hã (aquele do "outro lado da terra", o Dono do Rio e uma transformação da sucuri), dois seres associados ao universo reprodutivo araweté e particularmente relacionados às lógicas corporais femininas. Falarei, em primeiro lugar, da relação do Lua com a menstruação, bem como do desaparecimento do astro durante o período gestacional. Descreverei depois os perigos da aproximação do Dono do Rio durante a gravidez e das características do acréscimo de sua matéria seminal no embrião. Esboçarei também, ao longo do texto, uma contraposição das duas figuras, evidenciando outros elementos cosmológicos associados a um e a outro e as características ou os efeitos de sua aproximação. 


\section{O vermelho de lua}

"Jahi não é que nem a gente?", um jovem certa vez me esclareceu, enquanto me explicava sobre a causa da menstruação. Ele me dizia então que todos os meses o astro aparece para as mulheres, mesmo que elas não se lembrem, e faz sexo com elas. "Ele também tem hakuĩ hatĩ ["pênis duro"] igual ao homem. Quando namora imotome ["faz mole"], vai amansar". Mas o pênis de Lua tem uma característica específica: ele é descomunal, e acaba machucando a sua vítima: konomi apa-hã ujaikã, "o útero se quebra". Segundo algumas versões, é isto que provoca o sangramento. Segundo outras, é apenas o sexo com ele que tem esta capacidade de mo-eji, "fazer descer" o sangue acumulado no interior da mulher.

O que gera a matéria menstrual, contudo, não é o Lua. Tampouco o próprio corpo feminino. Segundo me explicaram, é a substância masculina: o sêmen dos parceiros se acumula e se transforma ao longo do mês no útero da mulher, saindo regularmente na forma de menstruação. Ou seja, se uma mulher menstruou, é porque teve relações sexuais durante o período, e o seu sangue é o resultado dessas conexões. Se ela não menstruou, há uma razão: ela igualmente teve relações sexuais, mas agora o sêmen se acumula para formar o embrião. Na presença ou na ausência de menstruação, se bem compreendi, a única conclusão é de que a mulher tenha sido ativa sexualmente no período.

Uma interessante noção está contida aqui. Vemos que há dois possíveis efeitos da introdução de sêmen: a menstruação, quando a substância é liberada; a gestação, quando ela se converte no embrião. Mas desconheço haver um evento determinante que efetive a concepção. A gestação está conectada com as relações sexuais prévias de uma mulher - é necessário ter tido relações sexuais para engravidar - mas nem toda relação sexual termina em gravidez. Não obstante, se uma mulher tem relações sexuais desde o início da puberdade (pois é o sêmen mesmo que a faz se desenvolver e menstruar), por que somente em certas ocasiões ela fica grávida?

Em outros contextos ameríndios, a concepção é produzida por certas agências. Schaden, por exemplo, dizia que para os Ñandevá as divindades enviavam a criança por meio do sonho (1962:111; ver o mesmo para os Mbyá, em Pissolato 2007:267; Heurich 2011:34; Mendes 2017). Entre os Tupinambá, segundo Abbeville (citado em Fernandes 1989:96-97), os espíritos de parentes mortos se inseriam nas mulheres. Fausto (2001:391) escreveu que as Parakanã engravidam quando uma alma -onga, que habita cursos d'água, se introduz no ventre feminino durante o banho (ou no pênis do homem e, após o sexo, na mulher). Há ainda explicações que notam 
eventos específicos: as Paumari (Bonilla 2007:158), por exemplo, devem retraçar os alimentos ingeridos no dia da relação sexual fecundadora (ocorrida no período final da menstruação) para identificar qual deles formou o princípio imaterial da criança; as Pirahã podem engravidar em decorrência de um susto (Gonçalves 2001:227). As explicações são muitas, mas não ouvi nenhuma parecida dita por mulheres ou homens araweté. Ao contrário, segundo compreendi, não existe uma diferença de natureza entre a matéria da menstruação e a da gestação. Talvez se passe algo análogo ao processo notado por C. Hugh-Jones (1979:116) entre as Barasana: a mãe deve ser progressivamente "preenchida" por relações sexuais repetidas, até que a alma (soul-stuff), derivada do sêmen paterno, seja suficientemente formada. Na gestação araweté, semelhantemente, não há introdução de princípio vital do exterior: tudo do feto é formado pela matéria seminal masculina, que se acumula no ventre. ${ }^{2}$

William Crocker conta que, para os Bororo, o sêmen é equalizado ao sangue e é denominado "sangue branco". De acordo com eles, o sangue que corre nas veias é a origem do sêmen masculino: há um órgão em específico, os testículos de mamíferos, responsáveis "for the transformation of one fluid into another" (1985:44). Segundo compreendo, há um processo análogo, mas invertido, na concepção araweté. O útero (konomi apa hã), e não os testículos, teria a função de transformar as substâncias: não o sangue em sêmen, mas o sêmen na matéria corporal do filho, sangue (wi), carne ( $\left.h a^{\prime} a\right)$, osso (xĩ), pele (pide) e princípio vital (î̀).

O ponto é que todo sangue menstrual é o sangue de uma gestação em potencial. E a possível etimologia do termo para ta'ire, "sêmen", parece indicar o mesmo: ta'i é a palavra para filho, filhote, criação (de qualquer tipo, humano ou não humano); -re é a marcação do pretérito de nomes, aqui designando o sêmen "objetificado", exterior ao corpo masculino (Viveiros de Castro 1986:437). Qualquer descarga masculina é potencialmente um filhote; qualquer menstruação é a não continuação de uma possível gestação (a este respeito, ver tb. Rodgers 2002:107; C. Hugh-Jones 1979:139; DaMata 1976:83, n. 11).

Para não engravidar, um homem tem de "derramar" (hakawa) seu sêmen durante o sexo. Inversamente, a forma de incentivar um casal a engravidar é dizer ao homem, geralmente em tom de chacota, que ele "não derrame nada", "nem uma gota". O sêmen é em qualquer instância fecundador e a sua injeção (-marã pipe) deflagra na mulher a capacidade "contenedora" de seu corpo: ela é o hiro, o "envoltório" que contém a matéria e que ocasionará a conversão do sêmen em embrião. Quando engravida, ela não produz sangue menstrual - "o Lua esquece dela", dizem. Ela continua 
acumulando matéria em seu interior, não a libera na forma da menstruação. O seu útero irá herowã - "transformar transformando-se" (Viveiros de Castro 1986:439; ver Mccallum 1999) o sêmen em embrião. Ela ocasiona, ou incita, a autofabricação do sêmen: "mediante", "por meio" dela (-opi) o embrião "se causa" (odzimo) ou "se faz" (odzimõñ̃).

Mas o mais frequente é que uma mulher não comunique ao marido, nem a ninguém, sobre a gravidez até mais ou menos o terceiro mês sem menstruação. Elas dizem não querer criar expectativas, pois é comum que essa gestação se suspenda naturalmente na forma da menstruação - algo que reforça minha percepção da passagem contínua entre a matéria da menstruação e a da gestação. Quando a gestação não tem continuação, diz-se que a mulher mokãnĩ, "faz perder" o embrião - ele "some", como me disseram em português. Nesse caso, ela menstruará normalmente em seu período lunar, devendo seguir as restrições normais de qualquer menstruação, que não são muitas. Aqui não há, como em outros lugares, uma proibição generalizada de cozinhar, pois o odor do sangue menstrual (hawia $\left.\underline{a}^{\prime} \tilde{a}\right)$ não pode ser transmitido por essa via. A única forma de contágio por via do odor, até onde tenho conhecimento, é se o marido deitar a cabeça no colo da mulher: devido à proximidade com o cheiro, ele ficaria zonzo e desmaiaria (sobre odor do sangue e transmissão, ver Overing 2006:43; Belaunde 2006, 2005; Garnelo 2003; Fausto 2001:310; Mccallum 1999, 2001; Andrade 1992; Gallois 1988; Albert 1985, entre muitos outros). Ela poderá então cozinhar normalmente, exceto o café, que ela pedirá a outra mulher ou ao marido para prepará-lo. Ela tampouco pisará açaí e, no caso de uma excursão para bater timbó, seu marido não poderá manusear o cipó. ${ }^{4}$

Em todo caso, há duas interdições especialmente danosas. A primeira diz respeito ao contato direto com o sangue da menstruação. A mulher deverá avisar o marido assim que descer seu sangue para que eles não venham a ter relações sexuais, ou ele sofreria uma morte sobrenatural chamada ha'íwã. Qualquer outra pessoa, aliás, que tenha contato direto com a substância - como ao se sentar numa rede onde ela sangrou - também morrerá pela mesma causa. Por isso, ela deve ser especialmente cuidadosa nesse período, sendo particularmente asseada e disponibilizando outros suportes para o marido ou os convidados se acomodarem. A segunda diz respeito ao rio. Se uma menstruada imergisse nas águas do rio, ou mesmo numa grota, a água invadiria seu ventre e uma tempestade incontrolável cairia sobre a terra, fazendo-a inundar. Segundo explicou a velha Moinowihi, isto faria o iwikati, o mundo aquático subterrâneo, subir para o estrato terrestre. Hoje, contudo, não são todas as mulheres que respeitam essa proibição no seu período menstrual. No resguardo pós-parto, porém, ela é estritamente observada, 
e também o era no resguardo do matador após o homicídio: ele também deveria banhar-se apenas entornando água de uma cuia sobre seu corpo, e a uma distância considerável do rio, de forma que o líquido derramado não encontrasse o fluxo fluvial.

\section{O sêmen demiurgo}

Quando o sangue menstrual não desce por alguns meses, a mulher assume sua gestação para si, para o marido e para os parentes próximos. Há duas fases diferentes da gestação, que podem ser discernidas por meio da atividade sexual de um casal. Durante os primeiros meses, a mulher deve receber constantes injeções de sêmen e, segundo muitos afirmavam, não só de seu marido. Idealmente, explicaram-me os mais velhos, mistura-se (moparã) a substância de até no máximo quatro homens - se mais, o bebê pode nascer com a pele manchada. Com a mistura, a criança nasce dura e forte (hatĩ). Atualmente, alguns casais jovens não apreciam esse ideal: os maridos são ciumentos, disseram-me, e não gostam de compartilhar a esposa. Falaram também que os bebês misturados, por serem duros, machucam a mulher durante o parto, "matam mesmo". Todavia, com ou sem o auxílio de outros homens, os maridos devem esforçar-se por "fazer esquentar" (moaku) o feto e "fazer inchar" (mowo) o ventre da esposa. A progressão do aumento da barriga é diretamente dependente da quantidade de sêmen introduzida. A duração da gestação depende do afluxo seminal.

Eis porque os maridos dizem ficar cansados na gestação de suas esposas: eles devem ter relações sexuais frequentes até quase os últimos meses. "Filho dá muito trabalho para fazer", disse um homem que não se conformava com o parto de um natimorto. Assim se referem os Araweté a tal atividade, e a ideia de "trabalho" talvez não seja fortuita: trata-se dos poucos afazeres masculinos (além da abertura de roças) que são assim considerados. Como as roças, é uma atividade que não existe no mundo celeste, um lugar onde só há ocupações prazerosas, como a caça, a dança, o cauim e o embelezamento. Faz-se muito sexo no céu, mas ali não é necessário se empenhar na tarefa de fazer crescer o feto: ele cresce sozinho.

Quando a barriga da mulher já está grande, porém, cessam as relações sexuais. É o que tomo como a segunda fase da gestação: quando o feto já está quase completo e não é necessário complementar sua matéria. O último elemento a ser gerado é o cabelinho, o único elemento que o sêmen não produz. Um feto "ganha" o seu cabelo dos bebês já nascidos, e não é incomum ver crianças de até um ano sem alguns tufos - ela própria os 
arranca, disseram-me, para presentear o embrião na barriga de outra mulher. Desconheço os motivos para isso, tampouco se existe alguma relação entre o doador e o receptor de cabelos.

Em todo caso, nos últimos meses o embrião já recebeu a quantidade de sêmen necessária para se fazer. Mas isto não quer dizer que ele está pronto: está "verde" (dzaxi) ainda. Um velho me contou que, se um homem faz sexo com uma mulher nesse período, um "espírito" - o - $a^{\prime}$ owe, aspecto imaterial que compõe os seres - entrará no corpo do homem após o parto e sua barriga inflará (-apũ), gestando algo como uma "gravidez fantasmal" (Lima 2005:133). Outros apenas disseram que, como consequência do sexo tardio, o bebê nasce envolvido por uma camada branca interna à placenta, o sêmen, cuja transformação em feto não se realiza.

Essa diferença de fases existe em razão dos distintos momentos da fabricação embrionária. No início da gestação, o que se acumula no interior da mulher se torna matéria coagulada, mas ainda bastante fluida. Uma mulher e seu marido me explicaram a constituição do embrião, após terem abortado nos primeiros meses de gestação. Quando perguntei se já havia na barriga um corpo igual ao nosso, eles disseram que não: é só $i$ ("líquido, água"), só ta'ire ("sêmen") - e o homem me perguntou se eu nunca havia visto o cadáver da queixada fêmea com um feto na barriga: e'e herī, $i$, "é igual, é líquido/água". Aquele ser que está se formando não tem corpo, é liqueforme; ele não é mìde, "nós", afirmaram. ${ }^{5}$

Trata-se de uma propriedade "constitutiva" do embrião. Há um acúmulo de líquido no útero que se "autofabrica", mas que também é produzido pelas ações dos pais. Uma só injeção de sêmen, sabe-se, não é suficiente para que o embrião se faça - e sem o envoltório materno, a massa não pode se transformar. Mas há mais: as atividades e as relações tidas pelos pais e pela mãe durante o período gestacional também afetam a "forma" da fabricação. Essa massa é fluida, está se formando "corpo", mas eis o ponto, ainda não o é. Ao menos no começo da gestação, ela é ainda completamente indefinida e, então, altamente transformativa.

Sempre que o tema da gravidez surgia em conversas, mulheres e homens aproveitavam para me ensinar sobre uma lista provavelmente ilimitada de proibições de alimentação e de atividades durante o período algumas restritas à mãe, outras aos pais, outras a ambos. Os itens listados podiam provocar transformações as mais variadas no feto. Os exemplos são muitos, mas aqueles de que obtive explicações diretas são bastante ilustrativos. Por exemplo, não se pode comer - nem mesmo mencionar jaboti sem um membro (zahixe), ou encontrado já morto (umanuxe), ou cujo fígado está muito grande (-pĩã-ho), pois o embrião se formaria com 
tais características. Também é interdito ovo de inhambu ou de galinha, pois o bebê ficará "desmaiando/morrendo" (umanu), como os filhotes desses animais. Tampouco devem ingerir comida "derramada" (hakawa), como bolachas que caem no chão ao abrir, ou "o olho do menino sai"; ou cará que criou muitas raízes no solo (karã pijuawi), ou o bebê terá "os dedos tortos, aleijados". Também é interdito à mulher fritar comida, ou o bebê nascerá com bolhas na pele. Não deve tampar panelas, ou a boca do bebê se fechará no saco amniótico e ele não chorará ao nascer. Ao beber direto da boca da garrafa, o feto não virará no ventre materno. Se a gestante comer cabeça de peixe de qualquer espécie, o bebê poderá nascer "com cabeça grande" - ou, assim me disse um casal, "o bebê nasce igual peixe, nasce peixe".

A forma e o local em que o casal terá relações sexuais também produzem transformações na formação do embrião. Se o fazem sob o pé de tucum (juara'i), o filho sofrerá de um estado chamado hadi e terá surtos de insanidade com convulsões, além de acessos de lascívia excessiva e impulso de pular no fogo ou na água. Esse estado é provocado pelo Dono do Tucum, o Juara'i Ñã. Se o fazem no mato, o casal deve se deitar no sentido do eixo leste-oeste, ou "o leite (isto é, o sêmen) vai estragar", me disseram em português. Se o fazem na rede, devem ambos estar de olhos abertos (não me explicaram o motivo). E se o marido encostar a mão na vagina de sua esposa, o embrião crescerá com a língua para fora. Há também lugares recomendados: no chão da casa sobre a esteira, no pedral, sob o pé de babaçu, ou perto de uma árvore derrubada, pois o feto nascerá duro, forte.

O que parece estar em jogo aqui é a formação do embrião, mais especificamente, sua configuração corporal. De uma massa líquida, ele vai ao longo da gestação tomando um formato. A descrição araweté parece ressaltar, em um sentido, uma exterioridade do embrião em relação aos que os geram. A mãe é seu envoltório, ela é quem permite sua transformação, mas não é ela quem o modela. Não ouvi explicações sobre o trabalho modelador do útero (como em Lima 2005:132; Calheiros 2014:248; ou da placenta, em Guerreiro 2012:151), e aqui a ênfase parece recair sobre a atividade do próprio sêmen. Mas o sêmen é uma substância destacada do homem (o que marca o sufixo -re). O pai irá fazer, com sua matéria, um novo corpo, mas esse corpo é externo a ele. Uma vez no útero, e uma vez atualizando sua capacidade transformativa, o sêmen-embrião irá se transformar. Mas tal condição autocriativa (fazer-se), bem como sua instabilidade corporal colocam-no em continuidade ontológica com o mundo e suas agências. Ele é aberto a diversas afecções, qualquer proximidade é perigosa, pois ele parece ser dotado de uma capacidade indiscriminada de comunicação. 
Vamos entender melhor a relação do embrião com os pais. Parece haver uma dupla disposição do ser que vem sendo formado: ele é ao mesmo tempo semelhante e diferente dos que o geram. Ele é uma massa produzida em e por eles, mas parece carregar uma abertura ontológica para fazer-se sob qualquer outra feição corporal, isto é, tornar-se "outro", diferente deles. E por isso também há um duplo dispositivo. Por um lado, os pais precisam esforçar-se para produzir e reforçar progressivamente a semelhança, e isto só pode ser feito ao cortar suas outras possíveis ligações com seres dotados da capacidade de também transformá-lo, restringir a gama de atividades que podem realizar. Ao mesmo tempo, a instabilidade do feto produz uma vulnerabilidade corporal nos próprios pais. Não há uma transformação de outro em si sem o perigo de tornar-se o outro também.

Se esse ser está se formando dentro de uma mulher, em um sentido ele também é a mulher. O "corpo" é denominado pelos Araweté hiro, um "continente", mas o corpo da mulher tem uma característica: ele encerra coisas em seu interior. O hiro da mulher é o envoltório também do embrião. Na gestação, ela é um ser que contém dois. Mas aquele que ela envolve não é "ela", sua matéria; ao contrário, é matéria do homem, que encerra a capacidade indiscriminada - e logo o perigo constante - de conexão com a alteridade. Assim, não é difícil entender como esse ser pode produzir também efeitos na formação corporal da mulher: a começar pelo inchamento de seu ventre, mas há mais. Se, por exemplo, ela come a carne de caça que fica enganchada na árvore, como macaco ou certas aves, o feto ficará preso em sua barriga. O mesmo acontece se ela usar penas de harpia: "kano-oho não tem unha? Vai segurar o menino". Comer o peixe cari ou o jacaré faz "hakapetī [tampar] o buraco dela". Tudo isso pode ocasionar a morte da mulher, no parto ou mesmo durante a gestação. Mas há outros efeitos menos fatais que apontam para a possibilidade de transformação também de seu corpo. Não penso ser exagero considerar os primeiros sintomas da gestação, que se dão nos meses iniciais, nesta mesma chave.

Konomi mide morahi: "menino deixa a gente doente", não cansavam de me explicar mulheres e homens sobre o início da gravidez. Qualquer diarreia, cansaço, febre que eu pudesse ter era rapidamente interpretado, como no caso acima, como sinais da gravidez que eles desejavam ver em mim. A gestante fica -tome, "mole, fraca", e emagrece nos primeiros meses. Toda comida "fica cheirando para a gente", elas contam: fica -da, "azeda". Elas têm muitos enjoos e vômitos (hemi'o poihi) e acabam se nutrindo de poucas coisas (peixinhos pequenos, cotia, cará, batata-doce, pipoca, bolacha) e evitam principalmente carne (de queixada e jaboti). Não escutei interpretações acerca da forma de ação dos odores - algo que recebe elaboração 
em outros contextos etnográficos (Gallois 1988:197; Overing 2006; Viveiros de Castro 2002a; Fausto 2001). Mas mesmo que não se possa considerar uma agência anímica ativada por este meio, o fato de o azedume atingir as mulheres nesse momento - e não em outros - parece-me apontar para uma abertura afectual e sensorial engendrada pelo seu estado gestacional, notadamente, esse estado em que seu corpo contém um "outro".

E é também nesse momento que as mulheres são dotadas de uma capacidade terapêutica particular: como as Aché, as gestantes araweté podem "retirar" dores corporais. Clastres (1995:183-184) conta que é o feto que possibilita tal operação, e também outras, como a previsão de fatos futuros, a aproximação de caça e de inimigos, a morte de alguém. O embrião aché "conversa" com a mãe de dentro de sua barriga. Entre as Araweté, o poder do embrião parece restrito à propriedade anestésica: se alguém apresenta uma dor, principalmente muscular (he ra'a rahi, "minha carne dói"), a gestante irá paka paka ("mexer, fazer massagem") no local e logo a dor irá sumir. Explicaram-me que a causa se encontra no embrião em sua barriga e que o poder se manifesta apenas nos primeiros meses da gestação, no momento em que ele ainda é liqueforme, moldável.

Existe na gestação uma conexão entre a mãe e o bebê. Mas eles são seres em alguma medida "autônomos", capazes de efetivar suas próprias relações. É sua extrema conjunção corporal, contudo, que propicia que atuem um no outro. Com o pai sucede algo semelhante: sua conjunção com o feto é substancial (ou seja, o feto é feito do sêmen paterno), mas, apesar de partilharem uma mesma substância, eles estão destacados um do outro. A mulher é o dispositivo corporal que medeia a transformação da substância masculina em "filho" - o homem precisa acionar a relação com alguém de sexo cruzado para poder fabricar um novo ser. A substância dele forma o corpo do embrião na mãe. E o embrião forma o corpo dela: ela transforma-se por meio do sêmen que se autotransforma em embrião. A matéria injetada é - visto do exterior - ela, pois seu corpo o envolve; mas simultaneamente é não ela, pois é matéria autônoma, destacada dela. Certas ações afetam o ser gestado, mas irão também afetar a mulher que o gesta. Se o marido come jaboti grande (ja'axi oho), ou mata uma harpia (kano-oho), o corpo da mulher não se abrirá e o feto ficará preso em sua barriga, por exemplo. Se ele comer rabo de tatu, o feto não virará para o parto. Se ele cortar as bandas de uma presa morta ou uma castanheira, ele provocará aborto (modzaxirã). A lista também é grande.

Em suma, o sêmen se faz (ozimoni), mas nada garante a forma dessa fabricação. Tudo o afeta, ele está aberto a travar relações com quaisquer seres, pois ele possui uma disposição generalizada de simbiose. É pura 
intensidade, com uma capacidade de se tornar qualquer ser. Justamente por isso ele é pura transformação. Ainda na barriga, ele não travou qualquer relação estável, ele não tem memória. Não "conhece" seus pais, não sabe discerni-los. É verdade que ele está em conexão com sua mãe, que o envolve, e com os homens que lhe fornecem a substância, mas - este é precisamente o risco - nada garante o que mais afeta sua formação. Se ele pode vincular-se indefinidamente com inúmeros seres, os pais e quaisquer outros, é porque ele não está ligado de forma estável a nenhum. Qualquer forma que venha a tomar é reversível, pois qualquer estado é momentâneo.

Mas a gestação engendra também a disposição comunicacional entre mãe-embrião-pai. A necessidade constante de intercursos sexuais, a injeção seminal frequente, o envolvimento do feto e sua disposição transformativa operam uma espécie de conjunção, em que as afecções de um contra-atuam nos outros. Assim, se o bebê é "aberto" e vincula-se indiscriminadamente, suas relações afetam não apenas ele, mas toda a "unidade mística" (Viveiros de Castro 1986:439, n. 88) criada com a gestação. Não se trata propriamente de fusão substancial entre os três, ou não apenas disto, pois o que está em jogo é principalmente uma transferência de afecções - a participação entre um e outros.

\section{O assalto da cobra-grande}

A menstruação, como vimos, é estritamente relacionada com o Lua, que é quem moeji, "faz descer (o sangue)". Já o estado gestacional atrai outra figura: a cobra-grande. Há várias interdições nesse sentido. Ensinaram-me que um homem que "está fazendo" seu filho não pode sair para pescar sozinho: a mai-aho (sucuri) iria atacá-lo no barco. Tampouco pode caçar: existe a moi-ho (jiboia), "irmã da mai-aho", em cuja proximidade há uma quantidade enorme de jabotis, de forma que o homem será atraído pelas caças e será pego e morto pela cobra. Para não atraí-la, o homem deve pedir a outros homens que o acompanhem, mesmo se for a locais não muito distantes da aldeia, como nas proximidades das roças. Já a gestante pode atrair esses seres quando vai a um passeio para mariscar - frequentemente no retorno desses passeios há relatos de se ver uma sucuri. Contudo, o ataque feminino não é do mesmo tipo do masculino: "Mulher não sai sozinha da aldeia. Como a mai-aho vai pegar?". A principal ameaça sofrida pela mulher não é a predação alimentar, mas sim sexual.

O pajé Tiñara'dido um dia me contava sobre o Iwikatihã (lit. "aquele do iwikatí, o outro lado da terra, isto é, o mundo subterrâneo"), ou o i ñã, 
"dono da água" e paranĩ ña a, "dono do rio". O estrato subterrâneo (iwikati) é caracteristicamente aquático: ali existem vários rios onde há piranhas gigantes (paku axo) e ilhas. Há diversos habitantes nas ilhas, mas o mundo inferior é domínio do Iwikatihã. Quando o pajé chega "para visitar", disse Tiñara'dido, ele é recebido pelo próprio Iwikatihã - a quem o pajé se dirige como he ramuĩ, "meu avô". O Dono da Água logo oferece comida para ele: "a gente chega, ele dá banana, dá peixe". Iwikatihã mostra seus xerimbabos para o pajé: "Essa é a casa do surubim, essa do trairão, essa do pacamão, essa da piranha, essa da piaba". Após mostrar todas, o ser então pergunta: "Qual você quer [comer]?".

Quando Tiñara'dido me contava tudo isso, eu aproveitei para perguntar se havia junto às outras casas uma casa da sucuri. Não, ele respondeu prontamente. "Iwikatihã odzidowã mai-aho, ele está virando mai-aho mesmo. Rápido, a gente nem vê. A gente pisca e ele está virando. Mai-aho não tem casa porque Iwikatihã mesmo que tem, é Iwikatihã mesmo... Jararaca é cobra mesmo, mas mai-aho não: mide ('é [a] gente'). Fica olhando a gente, aí vira, pega a gente, pra matar...".

A sucuri, então, é uma transformação do Iwikatihã. E, não por acaso, o Iwikatihã é o grande sedutor das mulheres. Quando uma mulher anda sozinha, a caminho da cacimba ou da roça, esse ser aparecerá para ela de improviso e a induzirá a ter relações sexuais. Por isso, uma mulher nunca pode andar desacompanhada: se seu marido não caminhar com ela, ela deve se fazer acompanhar por outras mulheres, dizem. Mesmo na própria aldeia o Iwikatihã pode aparecer: às vezes, quando seu marido vai caçar e ela se encontra sozinha dentro de casa, ele bate à sua porta e, se ela o receber, o resultado será o mesmo do encontro na mata, o intercurso sexual. Dizem também que ele pode entrar escondido na casa, em alguma hora do dia, e manter-se oculto no canto reservado ao estoque de jabotis vivos (ja'axi dokã iwe), algo que existe em todas as casas araweté. ${ }^{6}$ Ele fará sua aparição no momento oportuno, quando ali não estiver o marido.

Ele não se mostra às mulheres como sucuri. Dizem que o Iwikatihã é um homem bonito, sempre pintado de urucum, com brincos gigantes de penas coloridas. Ele não é um ma $\underline{i}^{7}$, uma divindade, ele é um tipo de "gente" (mide, nós). E sua beleza parece confirmar sua posição de sedutor: quando ele aparece para as mulheres, ele geralmente o faz sob essa forma atrativa, que torna difícil a recusa.

Todavia, ele também é dotado de um poder de se fazer perceber de outras maneiras: ele ujaruai, "engana" a mulher, ou seja, ele também pode se mostrar na figura de outros homens. Ele "fica virando igual o marido", dizem as Araweté, ou às vezes um outro homem por quem a vítima tenha 
desejo sexual. Sozinha em casa ou no caminho na roça, ela facilmente cederá à sua investida.

Parece estar em jogo uma capacidade própria do Iwikatihã de operar mudanças perspectivas. Num piscar de olhos, como disse Tiñara'dido, seu corpo se mostra como sucuri ao pajé ou como homem desejável à mulher. Talvez, também, ele se apresente ao marido da gestante de uma maneira análoga. Uma vez um homem me disse que, apesar da interdição, ele saía sozinho para pescar durante a gravidez de sua esposa: "é só não pensar na mai-aho", ele disse em português (palavra da qual nunca consegui um equivalente no idioma araweté). Se ele pensasse na sucuri, ele explicou, ela apareceria para ele e o comeria. "Pensar", sendo ou não uma atividade mental, comporta aqui um sentido comunicacional, equivalente ao ato da mulher de abrir a porta de sua casa ao Iwikatihã ou de responder a seu chamado nos caminhos no mato. É a abertura para uma relação.

Que o ser homem-cobra seja tomado como mide, "gente", já sabemos. Mas vários outros seres no cosmos araweté também o são, sendo humanos como "nós" (mide, gente, a gente, Araweté). Vivem em suas aldeias, com seus parentes e afins. O Iwikatihã, porém, é particularmente dotado de uma capacidade transformativa. Ele opera metamorfoses em si mesmo e também em seu interlocutor. Contudo, o período gestacional é especialmente propício a isso: trata-se de um estado de abertura corporal - o corpo do casal se abre por meio do sexo, a mulher infla por causa do embrião. Mas toda abertura corporal é também a ocasião para uma abertura cosmológica.

Lembremos da conjunção entre mãe-embrião-pai. Lembremos também que o ser que está sendo formado é instável, pois está em um fluxo de constante devir - ele não tem corpo, só tem "massa". Por isso, ele é particularmente dotado de capacidade metamórfica: associa-se indiscriminadamente e se transforma, mas, ao fazê-lo, ele "implica" também aqueles que o fabricam. Um pouco como o ser que estão gestando, o pai e a mãe abrem-se ao risco da indefinição: eles "perdem" um pouco de sua distinção corpórea, e então da perspectiva humana araweté. Perdem a propriedade de distinguir claramente entre as boas relações a serem travadas.

A brecha comunicacional engendrada com a gestação é uma circunstância para a concretização da perspectiva do homem-sucuri. Ao tomar a palavra ou o pensamento para se dirigir a esse ser, abrem-se as condições de possibilidade para efetivar o mundo que existe para ele (Lima 1996). É ele quem se torna sujeito na interação. Seja na forma de sucuri, seja na do belo homem, ele assume uma posição inequívoca de predador - sexual (quando humano) ou alimentar (quando ofídico). Seu interlocutor (o homem ou a mulher araweté) será reduzido, em correlação, à presa, pois será tomado pela perspectiva de 
seu interlocutor. Daí a necessidade das companhias: seja para pescar ou caçar, seja para buscar água ou ir à roça, a presença de parceiros é suficiente para neutralizar o risco da interação dual entre Iwikatihã e sua vítima.

É verdade que a predação sexual do Iwikatihã não tem lugar somente durante a gestação. Tampouco só com mulheres. Explicaram-me, por exemplo, que é proibido que um casal tenha relações sexuais na água: o "Iwikatihã namora com eles também". A substância dele entra no corpo, seja do homem, seja da mulher, e mide mopuruã, "nos faz grávidos". O mesmo acontece com uma mulher que use brincos de pena de japu quando está com diarreia, menstruada ou resfriada. O risco é idêntico quando ela faz sexo perto de uma grota d'água usando o ornamento. Se ela chora enquanto o usa, igualmente, o Iwikatihã se aproxima. Ele "acha que está falando com ele", explicou-me Arajohi, e o desfecho, segundo entendi, é levá-la para sua morada para casar-se com ele.

Não consegui explorar a relação entre a pena de brinco e o Iwikatihã, nem tive acesso a qualquer variação mitológica que conecte as aves à sucuri (como mitos do conjunto da "origem da cor dos pássaros" em outros contextos (ver Lévi Strauss 2004 e Gongora 2007; ver tb. Fock 1963:50 para a decoração com penas ensinada pelo povo-anaconda). Em todo caso, estas proibições que acabei de destacar relacionam o Iwikatihã com dois elementos específicos: água e pena. Além disso, elas têm como pano de fundo a ativação de orifícios corporais: a menstruação, a excreção, a secreção, a lágrima, o porte do brinco, a descarga masculina durante o sexo, a recepção desta pela mulher. Estas são mais que situações de incontinência corporal. Trata-se de orifícios tornados férteis, analogamente ao que narra Overing (2006:44) para os Piaroa. A abertura torna tais orifícios perigosos, mas não porque são "autofecundantes", como frisa a autora para aquele contexto. Sua ativação entre os Araweté parece ser, como o "riso reprimido" analisado por Lévi-Strauss (2004:53), uma "causa de abertura": ela viabiliza uma brecha cosmológica para a comunicação interespecífica.

A ativação dos orifícios (pelo sexo ou por processos fisiológicos), quando associada aos elementos do homem-cobra (água e pena), possibilita relações com esse ser, e então a fecundação. Não é uma "autofecundação" porque é justamente o contrário, é tão externa que transpõe domínios cosmológicos: a incontinência corporal possibilita a abertura para a ordem de realidade do Iwikatihã. Na perspectiva deste ser, o choro, a excreção, a secreção, o sexo não são apenas disposições corporais: são convites, são recepções. São análogos à comunicação proporcionada ao abrir a porta quando ele bate, ao pensar nele quando se sai sozinho para pescar, a atender ao seu apelo no caminho da roça. 
É interessante que no conjunto de mitos do riso reprimido destacado por Lévi-Strauss (2004:152) esteja incorporado o motivo das "moças da cobra", isto é, as mulheres "abertas", descomedidas tanto no sexo quanto no sorriso, que ficam grávidas de seus amantes-serpentes. Nos dois mitos retratados por este autor, os filhotes gerados são cobras: na versão munduruku, uma serpente que vingará a morte do pai; na toba-pilaga, as seis pequenas cobras que serão mortas e cuja mãe se transformará em iguana. Mas a propriedade erótica e a capacidade fertilizante das cobras - e da sucuri em especial - não são novidade no complexo cosmológico ameríndio. "Faites un tour du monde amérindien, vous trouverez mille animaux amoureux de femmes; faites un second tour, la moitié seront des anacondas amoureux de jeunes filles", afirmou Françoise Grenand em sua compilação de mitos wayãpi (1982:330).

Há muitas variações míticas que relatam a atração de mulheres pela cobra-grande (Grupioni 2002 citado em Gongorra 2007:149; Fock 1963:97; Vidal 2007; Lagrou 2007, 2015). Algumas, em específico, versam sobre as possíveis gestações ofídicas dessas mulheres. Cohn (2005:43), por exemplo, narra o desfecho de um mito em que os nascidos "parecia[m] Mebengokré, mas eram filhos da cobra". Em um mito Kraho (Melatti 1972:73), a relação sexual com a cobra gera uma criança metamórfica que, após queimada em uma fogueira, torna-se o primeiro branco. Entre os Wayãpi, a anaconda (moju) que seduzia mocinhas na menarca foi morta, apodreceu e de seu ventre saiu um novo povo (Gallois 1988:138ss.). O que se nota é que, em todos esses casos, o sexo tem um desfecho extraordinário, pois dá origem a seres outros: etnias diferentes, brancos, animais.

No caso araweté, não se trata de um mito, mas de uma série de registros presentes no cotidiano. São relatos sobre encontros sexuais entre o Iwikatihã e mulheres que acabaram falecendo; às vezes histórias de "quase" encontros, isto é, quando as mulheres se dão conta ainda a tempo do disfarce do homem-cobra e fogem. No mais das vezes, porém, a aproximação desse ser é revelada somente a posteriori, pelos efeitos do encontro. A relação sexual com o Iwikatihã também provocará (como nos mitos de alhures) uma gestação, mas não igual à concepção por parceiros araweté. A saída do feto fabricado com auxílio da cobra, que resulta quase sempre em aborto, revelará a gestação "monstruosa", provocada por esse ser, que se levava adiante. Geralmente, enquanto o feto ainda está na barriga, desconhece-se a conexão que se teve com o homem-cobra - o mais comum é que a pessoa nem saiba que travou relações sexuais com ele, tampouco que ele injetou algo dentro dela. Mas o parto revelará os efeitos de tal encontro: é quando então se toma ciência da relação pregressa com esse ser. 
Vimos que, ainda que o perigo seja menor, o Iwikatihã pode fecundar também homens. O sêmen do Dono do Rio irá se instalar no ventre masculino, que inchará. Todavia, o desfecho só pode ser mortal, pois os homens não possuem o aparato fisiológico para gestar (hnã i'apa). Nas mulheres, o efeito não é necessariamente letal, embora incorra sempre em fecundação. Já sabemos que não há, na concepção araweté, um evento específico que provoque o início da gestação, mas o sêmen do Iwikatihã tem uma característica hiperfecundante. Sua substância não chegaria jamais a ser liberada na forma periódica da menstruação, contrariamente à dos homens araweté (que sai após a injeção por Lua de seu próprio sêmen). O Lua "faz-descer" (moeji) o sangue. O Iwikatihã faz exatamente o contrário, "faz-engravidar". Quando aparece o Iwikatihã, o Lua desaparece, pois a substância do primeiro tem algo de "aglutinadora". Seu sêmen irá fecundar a mulher, ou se acrescentará à massa corporal já em fabricação, nos casos em que a mulher já se encontra grávida.

O sêmen do Iwikatihã não é como o dos Araweté. Este, como vimos, chama-se ta'ire. Já a substância do Dono do Rio tem outro nome: jawewi-rĩ, "futura arraia". Das relações sexuais com esse ser, os rebentos prototípicos são estes animais que, como quase tudo do mundo subterrâneo, são seus xerimbabos (demima). Mas o Iwikatihã pode injetar na mulher várias outras substâncias: marakañã na'i rĩ ("futuros filhotes de cachorro"), xiwã-nĩ ("futuros pentes"), tatã nĩ ("futuros fogos"). Ouvi histórias sobre a introdução de pequenos objetos, como fusos, fogo ou pedras - este último caso deu origem a tumores cancerígenos no aparelho reprodutor de uma mulher. E o sêmen do Iwikatihã fecunda não apenas as humanas. Um jovem certa vez me disse que eles abriram uma queixada morta na caçada e encontraram a gestação de cupu: "Iwikatinhã não salva nada, namora tudinho, porca, tatu, põe outra coisa nela".

O Iwikatihã, é fato, não é muito seletivo a respeito de seus alvos. Desde que certas condições sejam satisfeitas, ele investirá sobre mulheres solteiras, casadas e gestantes, mas também sobre homens e animais. Todavia, algo faz com que as grávidas sejam especialmente suscetíveis a seus ataques. A gestantes têm intensa atividade sexual, já que o embrião precisa ser fabricado e esquentado. A gravidez consiste em um estado prolongado de incontinência corporal, talvez até o maior estado de abertura vivido pelas mulheres, pois a gestação em si é aberta: além de dilatar o ventre feminino, ela também engendra um novo ser, isto é, acrescenta alguém ao mundo um ser que, como destaquei, é aberto à interação com variados seres e a diversas afecções. Abertura corporal, sociológica, cosmológica: a gestação é um bom pretexto para a aproximação do Iwikatihã. 
Mas é importante notar que raramente a gestação do Iwikatihã chega ao fim. Se no início seu sêmen tende a se concentrar no interior da mulher, na sequência a substância transformada irá sair. Modzaxirã é a palavra araweté para isso, que poderia ser traduzida por "abortar". O fruto do Iwikatihã é dito dzaxirã we ("aborto"), mas não só seres formados com sua substância são deste tipo. Vimos que o embrião tem uma forma "aberta" e pode se modelar diferentemente de acordo com distintas afecções recebidas ao longo de sua fabricação. Qualquer ser que se tenha criado em um formato corporal duvidoso será igualmente considerado dzaxirã we. $\mathrm{O}$ ato de modzaxirã provoca um superaquecimento do útero (é como se houvesse fogo dentro delas, dizem as mulheres), mas a expulsão da prole do Iwikatihã tem uma característica específica: ela é sempre uma multiplicidade (cf. tb. Lagrou 2007:225).

Quando uma mulher aborta o fruto do Iwikatihã, podem sair dela arraias, peixes, cobras, objetos, pedrinhas, mas a única certeza é que sairão dela incontáveis compostos desses conteúdos, de vários tipos, junto com abundância de sangue. Não nasce dela um filho do Iwikatihã, não se trata de filiação. O fruto dessa conexão não reproduz uma "identidade": seu corpo não é homólogo ao do ser que lhe forneceu substância. Tal rebento tampouco é um "ente", ele não tem determinação corporal, pois ele é uma multidão, e essa multidão é alheia à definição. De fato, pouco importa $o$ que surge da barriga da mulher, pois ele não tem característica determinada. O que ele tem é uma disposição específica: a de proliferar. Há algo de contagiante na conexão com o Iwikatihã, seja porque a multiplicidade se propaga em toda a massa elaborada no interior do ventre feminino, seja porque o próprio contato com uma mulher que gesta tal legião transmite a outras o risco análogo.

O fruto dessa gestação tampouco tem uma "existência" além do momento mesmo de sua gestação. Ele vive enquanto dentro do útero, mas sua saída implica a morte: sua e, às vezes, daquela que o gestou. Algumas mulheres não sobrevivem a um aborto deste tipo; no mínimo, sofrem uma morte temporária (umanũ, "morrer, desmaiar"). Iwikatihã procura as mulheres com um intuito específico. Ele quer roubá-las (imunã) e fazer delas suas esposas (temijika-mo). Às vezes, quando ele se relaciona com as mulheres fazendo-se passar por seus maridos, ou apenas inserindo seus objetos em seu interior, ele "passa doença". Seu aparelho reprodutivo arde com as arraias, os fogos, os fusos etc., ele "passa doença igual pente" e arranha por dentro. Mas a mulher não morre logo, ela vai ficando ikoji, magra. Fica na rede, "o marido fica chorando: 'onde está minha mulher?'", ele lamenta. 
Explicaram-me que "uma parte" das vítimas vai para o mundo subterrâneo junto com o Iwikatihã: é o seu ĩ, o "princípio vital" que o homem-sucuri deixa inicialmente preso em uma casa fechada ("com muito vigilante na porta", me disse um pajé). Nesse recinto só há a ĩ de crianças e mulheres - os alvos preferidos do Iwikatihã - que ele vai alimentando primeiramente com bananas, depois também com os peixes e as aves que são seus xerimbabos. Contudo, apesar da "vigilância", é possível trazer a ĩ de volta: um pajé o fará com o chocalho arai e o charuto de tabaco e tauari. A pedido do marido (no caso de esposa) ou dos pais (no caso da criança), ele irá buscar a parte do doente que foi parar lá. Nesse caso, o pajé e sua esposa irão para perto do doente - ou às vezes para a beira do rio - e se sentarão, enquanto a esposa acende o charuto e o entrega ao marido. Após alguns minutos fumando, o pajé começará a tocar o chocalho. No mundo subterrâneo, ele terá de achar o lugar onde está escondida a $\tilde{1}$, recebendo muitas vezes ajuda de Tarajo, o má $\underline{\dot{i}}$ que vive próximo ao Iwikatihã. Tendo-a encontrado, o pajé "carrega" (imone), com movimentos repetidos dos braços, o princípio vital, "trazendo-o de volta" (hero-jiwi) (ver Heurich 2015).

Se a mulher morrer, segundo entendi, sua transformação se efetiva: seu princípio vital permanecerá vivendo com ele, onde se fará novamente seu envoltório corporal (hiro-rõ, "novo envoltório corporal"). O sexo com o Iwikatihã, então, é uma ocasião para o rapto, e a gestação é o principal meio de aproximação entre ele e a mulher. O nascimento de um rebento fecundado por seu sêmen pode ser a ocasião de manter consigo a mulher na condição de esposa. Esta seria a forma de o Iwikatihã selar sua conjunção perspectiva com a mulher.

Contudo, a sequência metódica que descrevi acima não é uma explicação típica dos Araweté, nem mesmo das mulheres, que são normalmente mais claras e gostam de dar explicações. Ouvi relatos como os que citei acima, mas parece-me improvável que uma mulher narre a conjunção com Iwikatihã como uma história que tenha acontecido com ela. Fato é que nenhuma mulher assaltada por ele esteve consciente de seu logro. Se houve relações sexuais, ele provavelmente tomou a forma insuspeita de um de seus parceiros. Mas pode-se sabê-lo (ou suspeitá-lo) apenas a posteriori: o desenrolar dos eventos acabam gerando revisitações das histórias e reformulações dos episódios. Um aborto poderá por certo ser entendido de várias formas, mas na boca de outras pessoas talvez seja narrado como um encontro com o Iwikatihã. O que quero dizer com isto é que o sexo com esse ser raramente é algo que se conta em primeira pessoa - ele é quase sempre combustível para fofocas. Em todo caso, é 
interessante notar que a mesma lógica de rapto pela sucuri ocorre em outros contextos. Muito próximo ao que ouvi das Araweté, Gallois ouviu também de um Wayãpi que "a doença [mandada pela anaconda quando uma moça em resguardo entra em contato com seu domínio] não passa, aí morre. Sucuriju leva tay-wer dela, não vai para o céu, vai morar com y-jar [dono do rio] no fundo do rio" (1988:205)

\section{Lua <--> cobra}

Duas figuras surgiram neste artigo: Jahi e Iwikatihã. O primeiro é o Lua, que aparece mensalmente às mulheres, fazendo descer a matéria seminal que se acumulou no interior feminino por meio do sexo. O segundo é o Dono da Água, uma transformação da cobra-grande, que aparece para as pessoas - sobretudo mulheres - quando elas estão "abertas", principalmente por ocasião do sexo, da gestação, da menstruação. Nenhum dos dois é personagem de histórias que se contam sobre tempos antigos, ao menos eu não ouvi mitos sobre nenhum deles. ${ }^{8}$ Todavia, ambos são sujeitos que compõem o (e interferem no) cotidiano relacional araweté.

Jahi visita regularmente as mulheres e faz derramar seu sangue. Além da pontualidade, ele também responde por outra periodicidade. Ele tem um ciclo mensal: surge e fenece. Isso corresponde a um ciclo de vida: luas nascem e morrem. Os Araweté contam que cada lua é um "substituto" (jahi dõ, "outra/nova lua") do antigo. Mas a morte de lua não é exatamente "natural": ele é morto a machadadas por uma mulher chamada Marajama (Viveiros de Castro 1986:187). O detalhe, que contudo não me foi apontado pelos próprios Araweté, é interessante: lacerado pelo machado, sua morte faz derramar seu sangue.

Não ouvi histórias sobre a origem de jahi, tampouco mitos que associem Lua à menstruação. Em outros contextos ameríndios ${ }^{9}$ há histórias sobre a ocasião em que o Lua deflagrou a primeira menstruação feminina após subir ao céu com a face pintada de jenipapo, por ter cometido incesto com sua irmã. Entre os Araweté, até onde vai meu conhecimento, a origem da presença de Lua no céu não é motivo de muito interesse, tampouco as razões para as mulheres menstruarem. Todavia, embora Lua não tenha causado a menstruação em relatos míticos, ainda assim é ele quem origina o sangramento atualmente: ele "inaugura" as moças (jahi herowaro). Uma menina tem relações sexuais e em seguida jahi vem procurá-la, originando suas regras. Com ou sem mito, portanto, o astro e o processo fisiológico estão ligados, e não apenas na menarca, mas em todas as menstruações. Esta é a 
lógica prevista para o funcionamento do corpo feminino, que é, como vimos, mencionada no cotidiano.

Sobre o Iwikatihã, vimos que ele está associado à sucuri. E tanto a ele quanto a ela (e às vezes a ambos) estão associados detalhes importantes. Destaco em primeiro lugar o arco-íris (mapuku): como em outros lugares, esse fenômeno astronômico é uma sucuri (Lagrou 2007, 2015; Gallois 1988; Clastres 1995:27; ver Lévi-Strauss 2004:284; Belaunde 2006 e outros).

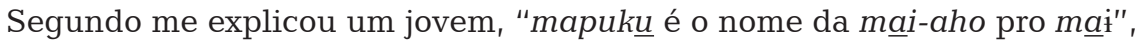
ou seja, é como as divindades mai - no seu linguajar próprio, diferente do dos Araweté - se referem à sucuri. Tenho a impressão, embora não tenha podido explorar mais a questão, de que se trata de uma disjunção perspectiva: o que para nós é arco-íris é sucuri para os habitantes celestes. E é por ele - pelo arco-íris - que os mại saem do céu ou o pajé ali adentra.

O arco-íris é uma espécie de porta, ou portal, que dá acesso ao mundo celeste: localizado na aldeia do Moiroxo, no caminho entre o estrato terrestre e o celeste, é a partir desse lugar que o mapuku "se faz grande" (odzimo howīhã) - como uma ponte (itajujurã) - para ser atravessado. Provavelmente por isso o arco-íris é também conectado com a morte: alguns dias após um falecimento, disseram, aparecerá um arco-íris - se bem entendi, é o modo com que o espectro - a'owe do morto acessa o céu. E o mapuku aparece também nas festas de cauim azedo. Certo dia, por exemplo, na iminência de uma festa em outra aldeia, apareceu um arco-íris; a velha Aradohi explicou então que era porque os ma $\underline{i}$ achavam que desceriam naquele dia ao estrato terrestre para comer o mingau. Abriu-se a porta do céu e a cobra mapuku se estendeu para que saíssem, mas percebeu-se a tempo de que se tratava de um engano e retornaram.

Como já sabemos, o Iwikatihã é associado ao domínio aquático: ele é também chamado de "dono da água" (i ñã) ou "dono do rio" (paranĩ ñã). Seja do Xingu, seja de igarapés, seja de grotas ou de pequenos cursos no mato, a água é domínio desse ser. É de se notar que em muitos outros contextos etnográficos a associação da cobra-grande com a água implica também a necessidade de cautela ao aproximar-se dela. Quase sempre se trata da interdição de contato do sangue com o domínio da anaconda. O sangue e seu cheiro são atrativos da cobra grande, segundo certos povos. Françoise Grenand conta que, segundo os Wayãpi, a sucuri "adore le sang et son odoeur, et recherche donc préférentiellement les femmes en période de menstruations ou en relevailles" (1982:24).

A explicação de Fock sobre o cheiro do sangue no mito wai wai sobre o povo-anaconda é interessante: após a menarca, a moça que fez aparecer o povo-anaconda não cheirava "para qualquer um", apenas para esse povo. Ela 
cheirava "pleasantly" para os homens-cobra, que a queriam como esposa, e não para os outros homens (Fock 1963:51, n. 8; ver tb. Calheiros 2014:36, n. 41; Rodgers 2002; Tola 2009; Lagrou 2007; Belaunde 2006 e outros). Entre as Araweté, contudo, o Iwikatihã não aparece apenas na menstruação. Segundo entendi, não se trata de uma atração particular pelo sangue. O sangramento é apenas uma das situações em que ele se faz presente, pois o homem-cobra surge em ocasiões de abertura corporal - algo que ocorre durante as regras, mas não só. Vimos, por exemplo, que durante a gestação o perigo de sua aproximação é iminente: contrariamente ao Lua, que desaparece com a concepção, o Iwikatihã é atraído pela abertura corporal própria deste estado. Tal qual em outros contextos, todavia, o contato com o homem-cobra sempre incorre no perigo da fecundação (ou no acréscimo seminal do embrião, se a mulher estiver grávida).

Lua e sucuri são duas figuras muito diferentes, mas estão ambas conectadas a um conjunto em comum de elementos: sangue, cheiro, abertura corporal, concepção, aborto, útero, beleza, sedução. Um estudo comparativo intenso sobre suas insurgências em mitos ou narrativas de outros contextos ameríndios certamente traria acréscimos importantes àqueles elementos, além de, suponho, acrescentar mais informações sobre a fisiologia e a condição femininas. Mas também as associações e as oposições entre Jahi e Iwikatihã no próprio pensamento araweté mereceriam uma análise mais elaborada, que terei, porém, de deixar para outra ocasião. A frequência periódica da lua, as aparições enganosas do Dono do Rio, o perigo ou não de sua aproximação, a relação de ambos com o sexo, com a beleza, com as aberturas corporais e com o cheiro pútrido, suas associações com fenômenos astrológicos, periodicidade e sazonalidade: o cruzamento de tais informações poderia levar a reflexões sobre os efeitos de Lua e do Dono do Rio no corpo feminino. Também mereceria mais considerações sua relação com o sangramento vaginal, isto é, o sangue considerado "podre" (iden me'e).

Um rapaz, quando me ensinava sobre tal categoria, notou que "tudo fica podre quando não cozinha". É curioso que tanto o sangue menstrual (resultado do contato com o Lua) quanto o material abortivo (gerado pelo encontro com o Iwikatihã) têm esta característica, e geram um efeito semelhante quando em contato com a água: uma espécie de cataclisma cosmológico (ver tb. Albert 1985:575). Se uma mulher com sangue imergisse no rio ou na grota, diziam-me os velhos, a água entraria no seu ventre fazendo-o inflar, mas também cairia do céu em tempestades infindáveis, fazendo o mundo subterrâneo emergir no estrato terrestre. Não tenho condições de desenvolver aqui, mas restaria ainda fazer uma análise sobre o "mundo podre" que se instaura nessas ocasiões, com a interrupção da sazonalidade 
típica do mundo terrestre e a aproximação entre estratos dos cosmos (por supressão de uma de suas camadas, a terrestre, e a aproximação do mundo aquático com o céu). Mas a condição líquida do mundo é também a ocasião de seu estado de maleabilidade, e para a constante mutabilidade das formas (Lagrou 2007:225). Uma condição de transformabilidade que é, talvez, semelhante à que se opera no útero ao fabricar-se a massa líquida coagulada ali.

Recebido em 08 de fevereiro de 2018

Aprovado em 18 de junho de 2018

Camila Caux é doutora em Antropologia Social. Trabalha e desenvolve pesquisas junto aos Araweté, povo de língua tupi-guarani que vive no Médio-Xingu. Dedica-se sobretudo a temas que envolvem concepções de corpo, gênero e parentesco, bem como a questões relativas à liberdade e à justiça reprodutivas. E-mail: camilacaux@gmail.com 


\section{Notas}

1 Este artigo é uma atualização pouco alterada de um dos capítulos de minha tese de doutorado. Agradeço a Aparecida Vilaça, Luisa Elvira Belaunde, Oiara Bonilla e Tania Stolze Lima pelos comentários. Agradeço também a vários amigos araweté, sobretudo a Itakarahi e Itakararo, pelos ensinamentos, bem como a Eduardo Viveiros de Castro, Guilherme Heurich e Luisa Girardi pelas conversas. Esta pesquisa contou também com o apoio do projeto "Ontografia comparativa e equivocação controlada: novos estudos etnográficos" (no âmbito do MCTI/CNPq n. 14/2012) e dos auxílios PPGAS/MN/UFRJ e Capes (2011/2 e 2013/1).

2 Sabe-se que em outros contextos etnográficos o sangue feminino também participa da fabricação do feto. Sobre isso, Aparecida Vilaça (2002) notou que, ainda que entre os Wari seja o sêmen o elemento prontamente apontado como a substância que forma o bebê, ao aprofundar as conversas, eventualmente surgiam explicações sobre a atuação também do sangue feminino. Florencia Tola (2009:153) notou uma mudança deste tipo nas respostas. Entre os Araweté, porém, a explicação exclusiva do sêmen era unânime. Acredito que não se trata, neste caso, de uma "illusion androcentrique qui a mis accent sur l'absence de participation féminine dans la création", como afirmou F. Tola (2009:154). Ao menos no que diz respeito aos Araweté, não é porque a mulher não fornece substância ao embrião que ela não participa na sua criação. Como veremos, a mulher é o continente (hiro) que "faz transformar" (herowã) sêmen em criatura - sem a ação feminina não seria possível fazer filhos, e os Araweté reconhecem explicitamente este ponto. Todavia, houve um único episódio em que uma jovem me disse que mulheres também fornecem substância. Quando lhe perguntei sobre as substâncias na concepção, ela me respondeu retomando um episódio recente de novela das nove, em que uma filha adotiva fazia um exame de DNA para comprovar sua relação genética com uma mulher. Se o DNA podia comprovar que suas substâncias corporais eram as mesmas, então tal compartilhamento devia existir: "é o mesmo sangue", a jovem me disse no momento, uma frase contrária à afirmação corrente entre mulheres e homens araweté de que o sangue é apenas do pai.

3 Ukani é "perder-se" (como em perder-se em algum lugar). Mo é um causativo. A palavra mokãni é comumente utilizada com o sentido de "esquecer": "fazer perder" uma ideia, um item, uma pessoa. No caso do embrião, considero a tradução literal "fazer perder" mais adequada, semelhante à tradução que me deram em português ("sumir"). A possibilidade de "esquecer" o feto seria interessante, mas não soube de outras noções que corroborassem tal tradução.

4 Segundo Garcia, as mulheres guajá não comem açaí, que tem, de acordo com esse povo, um "aspecto sanguinolento (hawy), e atuaria no sistema reprodutivo feminino" (2010:141). Não sei o motivo da associação feita pelos Araweté entre açaí, timbó e café - a noção de hawy dos Guajá poderia trazer uma luz a ela, justamente por denominar-se em araweté o odor do sangue derramado (apodrecido) de hawiã'á. O sufixo -ã'ã é usado para categorias de cheiro. 
5 Calheiros notou algo semelhante entre os Aikewara: "Diz-se do feto que é "só uma carne". Mas não uma carne qualquer, trata-se de uma carne mole, uma carne que se desfaz com o menor dos toques - e por isso mesmo uma carne que pode ser "modelada" (mu'apó'a, lit. "fazer-arredondado") pela agência de sua mãe" (2014:221). Entre os Araweté, porém, o útero não tem o mesmo trabalho modelador - ele é um "transformador", mas não um escultor. Além disso, a matéria liqueforme do embrião é também sangue, porém, diferentemente dos Araweté, para os Aikewara é "a carne de queixadas que fornece o sangue que o cozinhará no ventre da mãe".

6 Agradeço a Guilherme Heurich pela informação.

7 Ele não é uma divindade, mas vizinho dele reside o Tarajo e Motsyñã ačo, dois maï que também "perderam o maï ï'ã" (o transporte que levava os maï) no momento da separação do céu. Mas, ao contrário das divindades que subiram, os dois se instalaram no iwikati, o mundo subterrâneo. Interessantemente, existe uma operação perspectiva entre os diversos estratos: quando fazem seus rituais, os habitantes do iwikati não chamam os maï do estrato celeste para benzerem e compartilharem da refeição, como fazem os Araweté. Quem benze sua comida, ao contrário, são os habitantes do estrato dos Araweté viventes, os mesmos que chamam os maï celestes para comer na ocasião de seus rituais. Ou seja, os maï celestes são os que vêm comer em "nossas" festas (i.e., dos Araweté), mas somos "nós" (os Araweté) que vamos comer nas festas dos habitantes subterrâneos. Cheguei mesmo a ouvir que os habitantes desse estrato somos os maï dos moradores do Iwikati, por isso eles mïde mokaro, nos fazem comer. Nas tardes sonolentas na aldeia, em que todos estão mais preguiçosos, diz-se que é porque o pessoal do iwikati fez um ritual - tendo todos comido muito, agora dormem o dia inteiro.

8 Os Araweté não são de contar mitos ou, ao menos, não o faziam com espontaneidade, nem a mim nem entre si. Eventualmente, pedia a alguns amigos idosos para me contarem histórias - dois deles o faziam, embora jamais tenham contado alguma com estas figuras (mesmo após perguntas de minha parte).

9 Ver Huxley (1963:186ss.) para os Urubu Kaapor; Fock (1963:54) para os Waiwai; Lagrou (2007:241) para os Kaxinawa; Belaunde (2005) para muitos contextos. Para os Mbya, Heurich (2011:32) fala da conexão de Lua com o sangue, por um lado, e o mito do incesto e o jenipapo, por outro. Os Parakanã associam a primeira menstruação ao sangue que escorria das feridas de Lua, mas não ao incesto (Fausto 2012:3). Ver a excelente compilação de Luisa Elvira Belaunde (2006) sobre o sangue em vários contextos ameríndios, em que a associação entre sangue e Lua aparece com frequência. 


\section{Referências bibliográficas}

ALBERT, Bruce. 1985. Temps du sang, temps de cendres. Représentations de la maladie, système rituel et espace politique chez les Yanomami du sud-est (Amazonie brésilenne). Tese de Doutorado, Laboratoire d'ethnologie et de sociologie comparative, Université de Paris X.

ANDRADE, Lúcia. 1992. O corpo e o cosmos: relaçóes de gênero e o sobrenatural entre os Asurini do Tocantins. Dissertação de Mestrado, USP.

BELAUNDE, Luisa Elvira. 2006. "A força dos pensamentos, o fedor do sangue: hematologia e gênero na Amazônia". Rev. Antropol., São Paulo, v. 49, n. 1, jun. Disponível em: http://www.scielo. br/scielo.php? script $=$ sci_arttext $\&$ pid=S0034-77012006000100007

. 2005. El recuerdo de Luna: género, sangre y memoria entre los pueblos amazónicos. Lima, Peru: Fondo Editorial de la Facultad de Ciencias Sociales, UNMSM.

BONILLA, Oiara. 2007. Des proies si désirables: Soumission et prédation pour les Paumari d'Amazonie brésilienne. Thèse de Doctorat en ethnologie et anthropologie sociale, Paris, École des Hautes Études en Sciences Sociales.

CALHEIROS, Orlando. 2014. Aikewara: Esboços de uma sociocosmologia tupi-guarani. Tese de Doutorado, PPGAS/Museu Nacional-UFRJ.

CLASTRES, Pierre. 1995. Crônicas dos índios Guayaki: o que sabem os Aché, caçadores nômades do Paraguai. Tradução: Tânia Lima e Janice Caiafa. Rio de Janeiro: Editora 34/ Nova Fronteira.
COHN, Clarice. 2005. Relações de diferença no Brasil Central. Os Mebengokré e seus outros. Tese de Doutorado, PPGAS-FFLCH, USP.

CROCKER, J.C. 1985. Vital souls. Bororo Cosmology, Natural Symbolism and Shamanism. Tucson: The University of Arizona Press.

DAMATA, Roberto. 1976. Um Mundo Dividido: a estrutura social dos Índios Apinayé. Petrópolis: Editora Vozes.

FAUSTO, Carlos. 2012. "Sangue de Lua: reflexões sobre espíritos e eclipses". Journal de la société des américanistes, 98 (1). Disponível em: http://jsa.revues.org/12143.

. 2001. Inimigos Fiéis. História, guerra e xamanismo na Amazônia. São Paulo: Editora da Universidade de São Paulo

FERNANDES, Florestan. 1989. Organização social dos Tupinambá. São Paulo: Ed. Hucitec.

FOCK, Niels. 1963. Waiwai: Religion and society of an amazonian tribe. Nationalmuseet

Skrifter, Etnografisk Rakke, VIII. Copenhague: The National Museum.

GALLOIS, Dominique. 1988. O movimento na cosmologia waiãpi: criação, expansão e transformação do universo. Tese de Doutorado em Antropologia Social, USP.

GARCIA, Uirá. 2010. Karawara: a caça e o mundo dos Awá-Guaja. Tese de Doutorado, PPGAS - Faculdade de Filosofia, Letras e Ciências Humanas da USP.

GARNELO, Luiza. 2003 Poder, hierarquia e reciprocidade: saúde e harmonia entre os Baniwa do Alto 
Rio Negro. Rio de Janeiro: Fiocruz. GONÇALVES, Marco Antônio. 2001. O mundo inacabado. Ação e criação em uma cosmologia amazônica. Etnografia Pirahã. Rio de Janeiro: Editora da UFRJ.

GONGORA, Majoí. 2007. No Rastro da Cobra Grande: variações míticas e sociocosmológicas: a questão da diferença na região das Guianas. Dissertação de Mestrado, USP.

GRENAND, Françoise. 1982. Et l'homme devint jaguar: l'univers imaginaire et quotidien des Indiens Wayapi de Guyane. Paris: Editions L'Harmattan.

HUGH-JONES, Christine, 1979. From the Milk River: Spatial and Temporal Processes in North- west Amazonia. Cambridge: Cambridge University Press.

HEURICH, Guilherme O. 2015. Palavras quebradas, mundos citados e mortos esquecidos na arte verbal Araweté. Tese de Doutorado. Em preparação.

HEURICH, Guilherme O. 2011. Outras Alegrias: parentesco e festas Mbya. Dissertação de Mestrado, PPGAS/ Museu Nacional-UFRJ.

LAGROU, Elsje. 2015. O entre-dois do gênero na perspectiva do cipó entre os Kaxinawa. Comunicação oral. Seminário Foucault na Amazônia: sexualidades indígenas, UFRJ, IFCS, PPGAS.

2007. A fluidez da forma: arte, alteridade e agência em uma sociedade amazônica (Kaxinawa, Acre). Rio de Janeiro: TopBooks.

LÉVI-STRAUSS, Claude. 2004. O cru e o cozido. Mitológicas I. São Paulo: Cosac \& Naify.

LIMA, Tânia Stolze. 2005. Um peixe olhou pra mim: o povo Yudjá e a perspectiva. $1^{\mathrm{a}}$ ed. São Paulo/Rio de Janeiro: ISA/Editora Unesp/NuTI.

. 1996. "O dois e seu múltiplo: reflexões sobre o perspectivismo em uma cosmologia tupi". Mana, Rio de Janeiro, v. 2, n. 2:21-48. Disponível em: http://www.scielo. br/scielo.php? script=sci_arttext\&pid=S0104-93131996000200002.

MCCALLUM, Cecília. 2001. Gender and Sociality in Amazonia: How real people are made. Oxford, New York: Berg Publishers.

. 1999. "Aquisição de gênero e habilidades produtivas: o caso Kaxinawá". Revista Estudos Feministas, v. 7, n. 1 e 2. Dossiê Mulheres Indígenas. Disponível em: https:// periodicos.ufsc.br/index.php/ref/ article/viewFile/11990/11265

MELATTI, J. C. 1972. O Messianismo Craô. São Paulo: Herder/ Edusp.

MENDES, Luna. 2017. Gênero e corporalidade Mbya-Guarani: um olhar sobre a produção da pessoa. Dissertação de Mestrado, PPGAS do Instituto de Ciências Humanas e Filosofia da UFF.

OVERING, Joanna. 2006. "O fétido odor da morte e os aromas da vida: poética dos saberes e processo sensorial entre os Piaroa da bacia do Orinoco". Rev. Antropol., São Paulo, v. 49, n. 1, jun. Disponível em: http://www.scielo. br/scielo.php? script=sci_arttext\&pid=S0034-77012006000100002.

PISSOLATO, Elizabeth de Paula. 2007. A duração da pessoa: mobilidade, parentesco e xamanismo mbyá (guarani). São Paulo/Rio de Janeiro: ISA/Editora Unesp/NuTI.

RODGERS, David. 2002. "A soma anômala: a questão do suplemento no xamanismo e menstruação 
Ikpeng". Mana, Rio de Janeiro, v. 8, n. 2:91-125, out. Disponível em: http://www.scielo.br/ scielo.php?script $=$ sci_arttext $\&$ pid $=\mathrm{S} 0104-93132002000200004$.

SCHADEN, Egon. 1962. Aspectos Fundamentais da Cultura Guarani. São Paulo: Difusão Europeia do Livro.

TOLA, Florencia. 2009. Les conceptions du corps et de la personne dans un contexte amérindien. Indiens toba du Grand Chaco sudaméricain. Paris: L'Harmattan.
VIDAL, Lux. 2007. A Cobra Grande: uma introdução à cosmologia dos povos indígenas do Uaçá e Baixo Oiapoque-Amapá. Rio de Janeiro: Museu do Índio.

VIVEIROS DE CASTRO, E. 1986. Araweté, os Deuses Canibais. Rio de Janeiro: Zahar/Anpocs.

. "Esboço de cosmologia Yawalapití". In: A inconstância da alma selvagem. São Paulo: Cosac e Naify. pp. 25-86. 


\section{A LUA E O OUTRO LADO DA TERRA: MENSTRUAÇÃO, CONCEPÇÃO E GESTAÇÃO ENTRE AS ARAWETÉ}

\begin{abstract}
Resumo
O objetivo deste texto é descrever alguns aspectos da fisiologia feminina segundo o que me ensinaram os Araweté, povo indígena habitante do médio curso do rio Xingu (PA) e falante de um idioma da família tupi-guarani. Falarei da relação entre menstruação e concepção, da diferença entre matéria menstrual e gestacional, do caráter fecundador do sêmen e de sua propriedade auto-fabricadora, da capacidade "contenedora" do corpo feminino e do conjunto de restrições parentais durante a gravidez. Darei também ênfase para as figuras de Jahi (Lua) e Iwikatin-hã (aquele que vive do "outro lado da terra", ou o Dono do Rio), dois seres associados ao universo reprodutivo araweté e particularmente relacionados com as lógicas corporais femininas. Evidenciarei enfim alguns elementos cosmológicos associados a cada um deles e os efeitos de seu contato com as mulheres.
\end{abstract}

Palavras-chave: Arawete; menstruação; gestação; lua; sucuri.
MOON AND THE OTHER SIDE OF THE EARTH: MENSTRUATION, CONCEPTION AND PREGNANCY AMONG THE ARAWETÉ

\begin{abstract}
Abastract
This article describes some aspects of female physiology according to what I was taught by the Araweté, a TupiGuarani-speaking people of the middle course of the Xingu river (Brazilian Amazon). I will focus on the relation between menstruation and conception, on the difference between menstrual and gestational substances, on the self-fabricating property of semen, on the "container" capacity of the female body and on parental restrictions during pregnancy. I will also describe Jahi (Moon) and Iwikatin-hã (the one who lives on the "other side of Earth", or the Owner of the River), two figures associated with the Araweté reproductive universe, and particularly related to female corporeal logics. I will discuss some cosmological elements associated with each of them, as well as the effects of their intercourses with women.
\end{abstract}

Keywords: Araweté; menstruation; gestation; moon; anaconda 


\section{LA LUNA Y EL OTRO LADO DE \\ LA TIERRA: MENSTRUACIÓN, CONCEPCIÓN Y GESTACIÓN ENTRE LAS ARAWETÉ}

\section{Resumen}

El texto pretende describir algunos aspectos de la fisiología femenina según lo que me enseñaron los Araweté, pueblo indígena habitante del medio curso del río Xingu (Pará, Brasil), que habla un idioma de la familia tupi-guaraní. Hablaré de la relación entre menstruación y concepción, de la diferencia entre materia menstrual y gestacional, del carácter fecundador del semen y de su propiedad auto-fabricadora, de la capacidad "contenedora" del cuerpo femenino y del conjunto de restricciones parentales durante el embarazo. También haré énfasis en las figuras de Jahi (Luna) e Iwikatin-hã (aquel del "otro lado de la tierra", o el Dueño del Río), dos seres asociados al universo reproductivo araweté y particularmente relacionados con las lógicas corporales femeninas. Destacaré finalmente algunos elementos cosmológicos asociados a cada uno de ellos, y los efectos de su contacto con las mujeres.

Palabras-clave: Arawete; menstruación; gestación; luna; sucuri. 